Research Article

\title{
Xenomonitoring of Mosquitoes (Diptera: Culicidae) for the Presence of Filarioid Helminths in Eastern Austria
}

\author{
Sarah Susanne Übleis, ${ }^{1}$ Claudia Cuk, ${ }^{1}$ Michaela Nawratil, ${ }^{1}$ Julia Butter, ${ }^{1}$ Ellen Schoener, ${ }^{1}$ \\ Adelheid G. Obwaller, ${ }^{2}$ Thomas Zechmeister, ${ }^{3}$ Georg G. Duscher, ${ }^{1}$ Franz Rubel, ${ }^{4}$ \\ Karin Lebl $\mathbb{D}^{4}{ }^{4}$ Carina Zittra, ${ }^{1}$ and Hans-Peter Fuehrer $\mathbb{D D}^{1}$ \\ ${ }^{1}$ Institute of Parasitology, Department of Pathobiology, University of Veterinary Medicine Vienna, Veterinaerplatz 1, \\ 1210 Vienna, Austria \\ ${ }^{2}$ Division of Science, Research and Development, Federal Ministry of Defence and Sports, Vienna, Austria \\ ${ }^{3}$ Biological Station Lake Neusiedl, Burgenland, Austria \\ ${ }^{4}$ Institute for Veterinary Public Health, Department for Farm Animals and Veterinary Public Health, \\ University of Veterinary Medicine Vienna, Veterinaerplatz 1, 1210 Vienna, Austria \\ Correspondence should be addressed to Hans-Peter Fuehrer; hans-peter.fuehrer@vetmeduni.ac.at
}

Received 24 November 2017; Accepted 14 February 2018; Published 15 March 2018

Academic Editor: José A. Oteo

Copyright ( 2018 Sarah Susanne Übleis et al. This is an open access article distributed under the Creative Commons Attribution License, which permits unrestricted use, distribution, and reproduction in any medium, provided the original work is properly cited.

\begin{abstract}
Information on mosquito-borne filarioid helminths in Austria is scarce, but recent discoveries of Dirofilaria repens indicate autochthonous distribution of this parasite in Eastern Austria. In the current xenomonitoring study, more than 48,000 mosquitoes were collected in Eastern Austria between 2013 and 2015, using different sampling techniques and storage conditions, and were analysed in pools with molecular tools for the presence of filarioid helminth DNA. Overall, DNA of D. repens, Setaria tundra, and two unknown filarioid helminths were documented in twenty mosquito pools within the mitochondrial coxl gene (barcode region). These results indicate that $S$. tundra, with roe deer as definite hosts, is common in Eastern Austria, with most occurrences in floodplain mosquitoes (e.g., Aedes vexans). Moreover, DNA of D. repens was found in an Anopheles plumbeus mosquito close to the Slovakian border, indicating that $D$. repens is endemic in low prevalence in Eastern Austria. This study shows that xenomonitoring is an adequate tool to analyse the presence of filarioid helminths, but results are influenced by mosquito sampling techniques, storage conditions, and molecular protocols.
\end{abstract}

\section{Introduction}

In Europe, filarioid helminths of veterinary and/or medical relevance have mainly been documented in Mediterranean regions, but increasingly these pathogens are being reported in temperate climate zones in Central and Northern Europe as well [1-3].

The most important filarioid helminths in Europe are Dirofilaria immitis and D. repens, causing canine pulmonary (D. immitis), subcutaneous (D. repens), and ocular (mainly D. repens) dirofilariosis [4]. Both, D. immitis and D. repens, are zoonotic parasites [4]. The first Central European discoveries of D. immitis were confirmed in Switzerland, in
1995 and 1998 [5, 6]. Since then, both parasites, D. immitis and $D$. repens, have been described in humans (accidental hosts), dogs (definite hosts), and mosquitoes (vectors) in many Central European countries. Both filarioid species have now been shown to be present in all countries neighbouring Austria except for Liechtenstein, namely, Switzerland, Italy, Slovenia, Hungary, Slovakia, the Czech Republic (D. repens only), and Germany $[1,3,4,7-11]$. D. repens was documented in most Central European countries prior to D. immitis.

Mosquito-borne filarioid helminths of the genus Setaria mainly parasitize in the abdominal cavities of artiodactyls, hyracoids, and equines. Mosquitoes of the genus Aedes are thought to be the main vectors of these parasites 
TABLe 1: Number of mosquitoes and species collected in Eastern Austria included within this study.

\begin{tabular}{|c|c|c|c|c|c|}
\hline Mosquito species & $2013 \mathrm{HC}$ & $2014 \mathrm{HC}$ & 2014 Biodiversa & 2015 Biodiversa & Total \\
\hline Aedes cinereus/geminus & 6 & 6 & 299 & 33 & 344 \\
\hline Aedes vexans & 1718 & 1847 & 4417 & 1179 & 9161 \\
\hline Anopheles algeriensis & 4 & - & - & 3 & 7 \\
\hline Anopheles claviger & - & - & - & 13 & 13 \\
\hline Anopheles hyrcanus & 145 & 63 & - & 241 & 449 \\
\hline Anopheles maculipennis complex & 14 & 2 & 13 & 41 & 70 \\
\hline Anopheles plumbeus & 9 & 26 & 150 & 196 & 381 \\
\hline Coquillettidia richiardii & 2169 & 4333 & 1287 & 8034 & 15823 \\
\hline Culex martinii & - & - & 66 & 996 & 1062 \\
\hline Culex modestus & 31 & 8 & - & 61 & 100 \\
\hline Culex pipiens complex/Cx. torrentium & 2707 & 2090 & 2118 & 7124 & 14039 \\
\hline Culex territans & - & 8 & - & - & 8 \\
\hline Culiseta annulata & 4 & 7 & - & 33 & 44 \\
\hline Ochlerotatus cantans & - & - & 1 & 1 & 2 \\
\hline Ochlerotatus caspius & - & 51 & 17 & 4 & 72 \\
\hline Ochlerotatus cataphyla & - & - & 7 & 5 & 12 \\
\hline Ochlerotatus communis & - & - & 22 & - & 22 \\
\hline Ochlerotatus flavescens & - & - & 1 & - & 1 \\
\hline Ochlerotatus geniculatus & 4 & 41 & 20 & 6 & 71 \\
\hline Ochlerotatus intrudens & - & - & 24 & - & 24 \\
\hline Ochlerotatus japonicus japonicus & - & - & - & 6 & 6 \\
\hline Ochlerotatus leucomelas & - & - & - & 1 & 1 \\
\hline Ochlerotatus rusticus & - & - & 4 & - & 4 \\
\hline Ochlerotatus sticticus & 559 & 202 & 1113 & 499 & 2373 \\
\hline Uranotaenia unguiculata & - & - & - & 10 & 10 \\
\hline Aedes/Ochlerotatus sp. & a & a & 735 & 217 & 952 \\
\hline Anopheles sp. & a & a & 22 & 387 & 409 \\
\hline Culex sp. & a & a & 131 & 257 & 388 \\
\hline Total & 7370 & 8684 & 10447 & 19347 & 45848 \\
\hline
\end{tabular}

HC, Hook Company Traps; Biodiversa, combination of various traps including BG-Sentinel Traps, HC, and aspirators; ${ }^{a}$ mosquitoes specified to genus level were not included.

(e.g., Ae. vexans for S. labiatopapillosa) $[12,13]$. Setaria tundra is a parasite of roe deer documented in several European countries such as Austria, Switzerland, Germany, France, Italy, Hungary, Poland, Spain, and Denmark (summarized in Enemark et al. [14]). In Northern Europe, S. tundra can also be found in domestic reindeer, wild forest reindeer, and moose [15]. This species is associated with climate changes and causes severe outbreaks of periodontitis in semidomestic reindeer in Finland [16].

The aim of this study was to xenomonitor Eastern Austrian mosquitoes for the presence of DNA of filarioid helminths-with the main focus on Dirofilaria repens and D. immitis but also on Setaria tundra and other mosquitoborne filarioid helminths.

\section{Materials and Methods}

The present study combines the analysis for filarioid helminth DNA in mosquitoes sampled in two independent mosquito monitoring programs using two different storage conditions (dry and $-80^{\circ} \mathrm{C}$ ) conducted between 2013 and 2015 .

2.1. Mosquito Sampling Method 1. In 2013 and 2014, adult female mosquitoes were trapped at three locations in Vienna using new standard miniature light traps (John W. Hook Company, Gainesville, Florida) baited with $\mathrm{CO}_{2}$. Collection was carried out on a daily basis for 24 hours from March to October. Mosquitoes were killed using the insecticide dichlorvos as soon as they entered the trap. Once a week, the traps were emptied, and Culicidae were dried and stored at room temperature until further processing [17].

2.2. Mosquito Sampling Method 2. Mosquitoes were monitored across three provinces of Eastern Austria (Burgenland, Lower Austria, and Vienna) at 35 permanent and 23 nonpermanent trapping sites. At permanent sampling sites, mosquitoes were monitored on a regular basis every second week for a 24-hour time period from April to October 20142015 using Biogents Sentinel Traps (Regensburg, Germany) equipped with carbon dioxide as attractant. Nonpermanent sampling sites were investigated at least once and up to six times during the summer months using Biogents Sentinel Traps (Regensburg, Germany) or exhausters. All mosquitoes were stored at $-80^{\circ} \mathrm{C}$ until further processing [18].

Mosquitoes were identified morphologically using the identification key of Becker et al. [19] and pooled by species, collection site, and date, with a maximum number of 50 individuals per pool. To each pool, $400 \mu \mathrm{l}$ of DNA/RNA lysis buffer (Zymo Research Corp., USA) and two ceramic beads (Precellys Ceramic Beads, Peqlab Biotechnologie $\mathrm{GmbH}$ ) were added, and the samples were homogenized in a TissueLyser II (Qiagen, Germany). Approximately $350 \mu \mathrm{l}$ of 
TABle 2: Filarioid helminths in mosquitoes in Eastern Austria: Vienna, Lower Austria (LA), and Burgenland (B).

\begin{tabular}{|c|c|c|c|c|c|c|c|}
\hline $\begin{array}{l}\text { Filarioid } \\
\text { species }\end{array}$ & Mosquito species & Collection site & Sampling method & $\begin{array}{l}\text { Collection } \\
\text { date }\end{array}$ & $\begin{array}{c}\text { Pool } \\
\text { size }\end{array}$ & $\begin{array}{l}\text { GenBank } \\
\text { entry }\end{array}$ & $\begin{array}{l}\text { Maximum \% identity to } \\
\text { GenBank entries }\end{array}$ \\
\hline $\begin{array}{l}\text { Dirofilaria } \\
\text { repens }\end{array}$ & $\begin{array}{l}\text { Anopheles } \\
\text { plumbeus }\end{array}$ & Marchegg (LA) & BG-Sentinel & August 2015 & 1 & MF695085 & $100 \%$ \\
\hline $\begin{array}{l}\text { Setaria } \\
\text { tundra }\end{array}$ & $\begin{array}{c}\text { Aedes } \\
\text { cinereus/geminus }\end{array}$ & Lobau (Vienna) & $\mathrm{HC}^{\mathrm{a}}$ & July 2013 & 1 & MF695086 & $100 \%$ \\
\hline $\begin{array}{l}\text { Setaria } \\
\text { tundra }\end{array}$ & Aedes vexans & Marchegg (LA) & BG-Sentinel & July 2014 & 25 & MF695087 & $>99 \%$ \\
\hline $\begin{array}{l}\text { Setaria } \\
\text { tundra }\end{array}$ & Aedes sp. & Lobau (Vienna) & $\mathrm{HC}^{\mathrm{a}}$ & August 2014 & 9 & MF695088 & $>99 \%$ \\
\hline $\begin{array}{l}\text { Setaria } \\
\text { tundra }\end{array}$ & Aedes vexans & Lobau (Vienna) & $\mathrm{HC}^{\mathrm{a}}$ & August 2014 & 42 & MF695089 & $100 \%$ \\
\hline $\begin{array}{l}\text { Setaria } \\
\text { tundra }\end{array}$ & $\begin{array}{l}\text { Coquillettidia } \\
\text { richiardii }\end{array}$ & Lobau (Vienna) & $\mathrm{HC}^{\mathrm{a}}$ & August 2014 & 50 & MF695090 & $>99 \%$ \\
\hline $\begin{array}{l}\text { Setaria } \\
\text { tundra }\end{array}$ & Aedes vexans & Vienna & Aspirator & August 2014 & 1 & MF695091 & $100 \%$ \\
\hline $\begin{array}{l}\text { Setaria } \\
\text { tundra }\end{array}$ & Aedes vexans & Marchegg (LA) & BG-Sentinel & August 2014 & 3 & $\mathrm{nd}^{\mathrm{c}}$ & $100 \%$ \\
\hline $\begin{array}{l}\text { Setaria } \\
\text { tundra }\end{array}$ & $\begin{array}{c}\text { Aedes } \\
\text { cinereus/geminus }\end{array}$ & Eckartsau (LA) & BG-Sentinel & June 2015 & 1 & MF695096 & $>99 \%$ \\
\hline $\begin{array}{l}\text { Setaria } \\
\text { tundra }\end{array}$ & Aedes sp. & $\begin{array}{l}\text { Klosterneuburg } \\
\text { (LA) }\end{array}$ & BG-Sentinel & June 2015 & 25 & $\mathrm{nd}^{\mathrm{c}}$ & $100 \%$ \\
\hline $\begin{array}{l}\text { Setaria } \\
\text { tundra }\end{array}$ & $\begin{array}{l}\text { Culex pipiens } \\
\text { complex }\end{array}$ & $\begin{array}{l}\text { Bruckneudorf } \\
\text { (B) }\end{array}$ & BG-Sentinel & July 2015 & 50 & $\mathrm{nd}^{\mathrm{c}}$ & $100 \%$ \\
\hline $\begin{array}{l}\text { Setaria } \\
\text { tundra }\end{array}$ & Aedes sp. & $\begin{array}{l}\text { Götzendorf } \\
\text { (LA) }\end{array}$ & BG-Sentinel & July 2015 & 6 & MF695092 & $99 \%$ \\
\hline $\begin{array}{l}\text { Setaria } \\
\text { tundra }\end{array}$ & Aedes vexans & $\begin{array}{l}\text { Götzendorf } \\
\text { (LA) }\end{array}$ & BG-Sentinel & July 2015 & 50 & MF695093 & $100 \%$ \\
\hline $\begin{array}{l}\text { Setaria } \\
\text { tundra }\end{array}$ & Aedes vexans & $\begin{array}{l}\text { Götzendorf } \\
\text { (LA) }\end{array}$ & BG-Sentinel & July 2015 & 50 & $\mathrm{nd}^{\mathrm{c}}$ & $100 \%$ \\
\hline $\begin{array}{l}\text { Setaria } \\
\text { tundra }\end{array}$ & Aedes vexans & $\begin{array}{l}\text { Jennersdorf } \\
\text { (B) }\end{array}$ & BG-Sentinel & July 2015 & 1 & MF695094 & $100 \%$ \\
\hline $\begin{array}{l}\text { Setaria } \\
\text { tundra }\end{array}$ & Aedes sp. & $\begin{array}{l}\text { Bruckneudorf } \\
\text { (B) }\end{array}$ & BG-Sentinel & July 2015 & 4 & $\mathrm{nd}^{\mathrm{c}}$ & $100 \%$ \\
\hline $\begin{array}{l}\text { Setaria } \\
\text { tundra }\end{array}$ & Aedes vexans & $\begin{array}{l}\text { Bruckneudorf } \\
\text { (B) }\end{array}$ & BG-Sentinel & July 2015 & 26 & MF695095 & $100 \%$ \\
\hline $\begin{array}{l}\text { Setaria } \\
\text { tundra }\end{array}$ & $\begin{array}{l}\text { Culex pipiens } \\
\text { complex }\end{array}$ & Vienna & BG-Sentinel & August 2015 & 50 & $\mathrm{nd}^{\mathrm{c}}$ & $100 \%$ \\
\hline Filarioidea & Culex modestus & Vienna & $\mathrm{HC}^{\mathrm{a}}$ & June 2014 & 1 & $n d^{c}$ & $93 \%$ \\
\hline Filarioidea & $\begin{array}{l}\text { Culex pipiens } \\
\text { complex }\end{array}$ & Vienna & $\mathrm{HC}^{\mathrm{a}}$ & $\begin{array}{l}\text { September } \\
2014\end{array}$ & 1 & $\mathrm{nd}^{\mathrm{c}}$ & $95 \%$ \\
\hline
\end{tabular}

${ }^{a}$ Hook Company $\mathrm{CO}_{2}$ baited mosquito traps; ${ }^{b}$ analysis of maximum identity to GenBank Entries was performed on August 4, 2017; ${ }^{c}$ sequences were not uploaded to GenBank (e.g., short sequences or poor sequence quality).

the homogenized pulp was loaded onto a QIAshredder (Qiagen, Germany). The filled QIAshredders were centrifuged for two minutes at $13,000 \mathrm{rpm}$ to filter the samples (solid components remained on the column). In the next step, DNA was extracted using a ZR-Duet ${ }^{\mathrm{TM}}$ DNA/RNA MiniPrep kit (Zymo Research Corp., USA) according to the manufacturer's instructions.

DNA extracted from female mosquito pools was examined for the presence of genomic material of filarioid helminths using primers and PCR conditions published elsewhere [20]. The primers used target a $724 \mathrm{bp}$ fragment of the mitochondrial cytochrome oxidase subunit I gene and are specific for various filarioid helminths (e.g., Dirofilaria, Wuchereria, Brugia, Onchocerca, Setaria, and Acanthocheilonema). PCR products were separated by electrophoresis in $2 \%$ agarose gels stained with Midori Green Advance DNA stain (Nippon
Genetics Europe, Germany). Finally, purified PCR products were sequenced by a commercial company (LGC Genomics $\mathrm{GmbH}$, Germany). Sequences thus obtained were compared for similarity to sequences available in GenBank ${ }^{\circledR}$ database (http://www.ncbi.nlm.nih.gov/BLAST).

\section{Results and Discussion}

45,848 mosquitoes representing 25 mosquito species were analysed for the presence of filarioid DNA in this xenomonitoring survey (Table 1), resulting in the identification of DNA from D. repens, $S$. tundra, and two unknown filarioid helminths in 20 of the mosquito pools (Table 2; Figure 1).

DNA of D. repens was only found in 2015 in a single Anopheles plumbeus mosquito in Marchegg (Lower Austria) close to the Slovakian border. Although several mosquito 


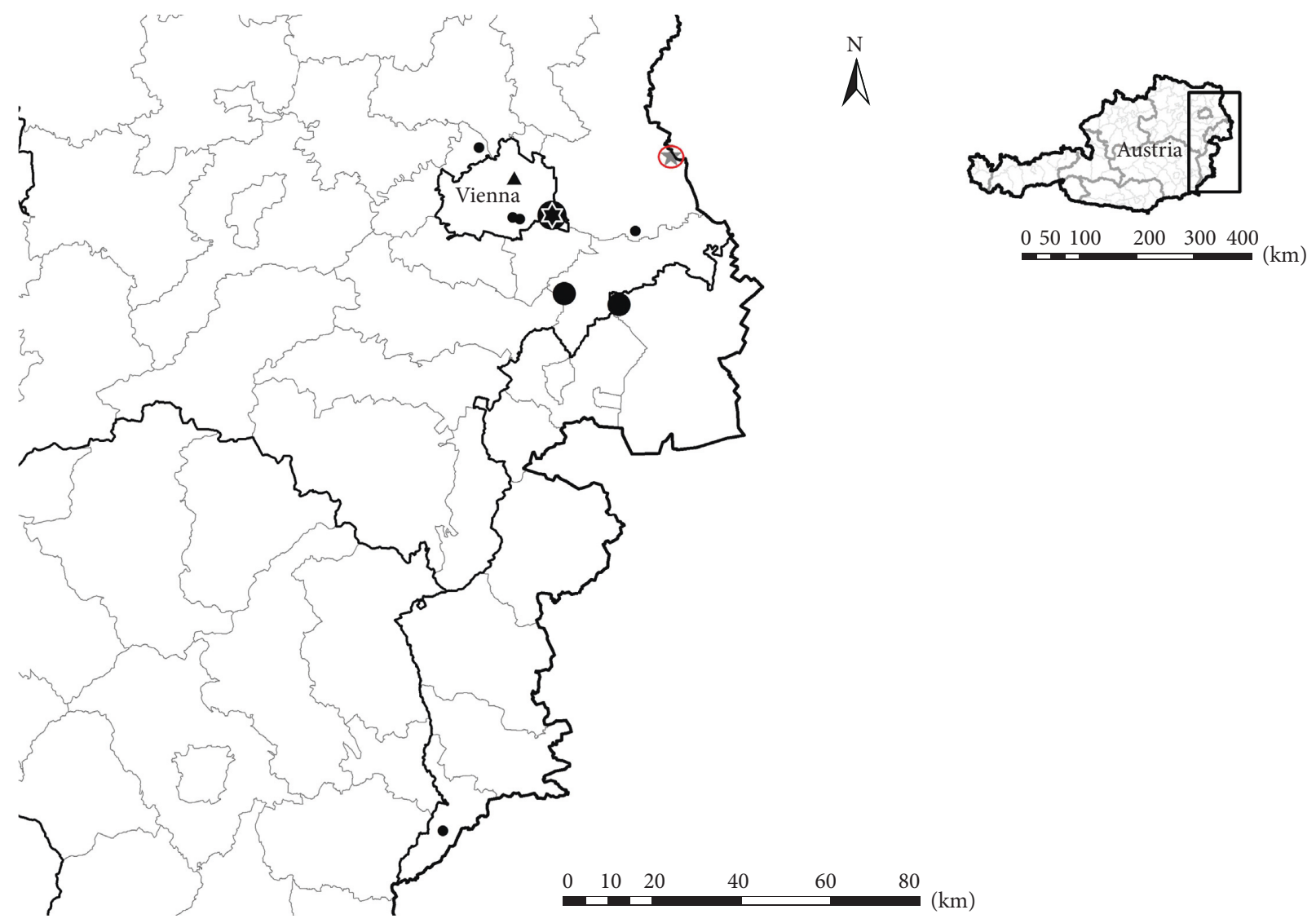

- S. tundra, 1 positive pool/location

S. tundra, 3 positive pools/location

S. tundra, 4 positive pools/location

D. repens and

S. tundra, 2 positive pools/location

A Filarioidea, 2 positive pools/location

FIgURE 1: Geographic distribution of mosquito pools positive for filarioid helminths in Eastern Austria.

species of different genera are proven as potential vectors of $D$. repens [21], DNA of this parasite has so far only been detected in other Anopheles species (An. algeriensis and An. maculipennis complex) in Austria [2].

To date, all $D$. repens positive mosquitoes have been collected in close proximity to the Slovakian (this study) and the Hungarian borders [2]. In both Slovakia and Hungary, D. repens is known to be endemic with a prevalence above $10 \%$ in dogs in the Bratislava area, close to the Austrian border [22, 23]. Previous metadata analysis has shown that most reported but also potential autochthonous findings in dogs were in Eastern Austria [10]. Furthermore, Duscher et al. [24] described the examination of D. repens positive dogs in the same districts where positive mosquitoes were documented (Gänserndorf and Neusiedl am See). This indicates that $D$. repens might be endemic with low prevalence in this area. Simon et al. [4] postulated that two preconditions are required for a successful establishment of $D$. repens and D. immitis in a novel area: (i) the presence of competent mosquito vectors, which is the case in Austria, and (ii) a certain number of positive dogs shedding microfilaria. The second precondition seems to limit the distribution of $D$. repens (but also D. immitis) because there are almost no stray dogs, and kennel holding is not common in Austria.

Dirofilaria immitis was not identified in the present large-scale survey, confirming previous results that this parasite has not yet established itself in Eastern Austria [10]. This pathogen has however been confirmed in dogs [22, 23, 25] and in mosquitoes $[26,27]$ in Slovakia and Hungary in the vicinity of our study area.

The most commonly found filarioid helminth within the present study area in Eastern Austria was $S$. tundra, with most occurrences of $S$. tundra DNA in mosquitoes of the genus Aedes, especially Ae. vexans. Similarly, prevalences of up to $12.3 \%$ have been reported in roe deer in Central Europe (e.g., northern Bavaria [28]). This parasite has also been recorded in Ae. vexans in studies in Germany and Hungary $[1,27,29,30]$, suggesting that $S$. tundra is a common parasite of roe deer in Eastern Austria. 
The discovery of DNA of unknown filarioid helminths in ornithophilic Culex mosquitoes ( $C x$. modestus and $C x$. pipiens complex) is not surprising because several avian filarioid helminths (with low pathogenicity for bird hosts) are present in Central Europe [29].

\section{Conclusions}

This xenomonitoring survey confirms the presence of DNA of certain filarioid helminths in mosquitoes in Eastern Austria and indicates possible vector competence of select mosquito species. However, comparison of the two sampling techniques and storage schemes used here suggests that storage of dried mosquitoes at room temperature increases the number of false negative pools because of a decrease of DNA quality, a circumstance that has also been noticed during analyses of mosquito DNA itself [31]. Moreover, different techniques for mosquito sampling (certain mosquito species are attracted by certain traps) and the use of different PCR protocols also influence the outcome of xenomonitoring studies [32]. Nevertheless, xenomonitoring is an effective tool to examine if certain pathogens are present in an area (e.g., [27]). It can be concluded that $D$. repens, $S$. tundra, and unknown filarioid helminths (most probably avian parasites) are present in Eastern Austria. Further studies are needed to monitor in more detail the situation of $D$. repens and $D$. immitis in Austria and neighbouring countries.

\section{Conflicts of Interest}

The authors declare that they have no conflicts of interest.

\section{Acknowledgments}

The authors thank all citizen scientists who helped in mosquito sampling within this study. Parts of this research were funded by the ERA-Net BiodivERsA, with the national funders FWF I-1437, ANR-13-EBID-0007-01, and DFG BiodivERsA KL 2087/6-1 as part of the 2012-13 BiodivERsA call for research proposals.

\section{References}

[1] M. Kronefeld, H. Kampen, R. Sassnau, and D. Werner, "Molecular detection of Dirofilaria immitis, Dirofilaria repens and Setaria tundra in mosquitoes from Germany," Parasites \& Vectors, vol. 7, p. 30, 2014.

[2] K. Silbermayr, B. Eigner, A. Joachim et al., "Autochthonous Dirofilaria repens in Austria," Parasites \& Vectors, vol. 7, p. 226, 2014.

[3] J. Matějů, M. Chanová, D. Modrý et al., "Dirofilaria repens: emergence of autochthonous human infections in the Czech Republic (case reports)," BMC Infectious Diseases, vol. 16, p. 171, 2016.

[4] F. Simón, M. Siles-Lucas, R. Morchón et al., "Human and animal dirofilariasis: the emergence of a zoonotic mosaic," Clinical Microbiology Reviews, vol. 25, no. 3, pp. 507-544, 2012.

[5] P. Deplazes, F. Guscetti, E. Wunderlin, H. Bucklar, J. Skaggs, and K. Wolff, "Endoparasite infection in stray and abandoned dogs in southern Switzerland," Schweizer Archiv für Tierheilkunde, vol. 137, no. 5, pp. 172-179, 1995, in German.
[6] H. Bucklar, U. Scheu, R. Mossi, and P. Deplazes, "Is dirofilariasis in dogs spreading in south Switzerland?," Schweizer Archiv für Tierheilkunde, vol. 140, no. 6, pp. 255-260, 1998, in German.

[7] C. Genchi, L. H. Kramer, and F. Rivasi, "Dirofilarial infections in Europe," Vector-Borne and Zoonotic Diseases, vol. 11, no. 10, pp. 1307-1317, 2011.

[8] E. Bocková, I. Rudolf, A. Kočišová et al., "Dirofilaria repens microfilariae in Aedes vexans mosquitoes in Slovakia," Parasitology Research, vol. 112, no. 10, pp. 3465-3470, 2013.

[9] C. Czajka, N. Becker, H. Jöst et al., "Stable transmission of Dirofilaria repens nematodes, northern Germany," Emerging Infectious Diseases, vol. 20, no. 2, pp. 328-331, 2014.

[10] H. P. Fuehrer, H. Auer, M. Leschnik, K. Silbermayr, G. Duscher, and A. Joachim, "Dirofilaria in humans, dogs, and vectors in Austria (1978-2014)-from imported pathogens to the endemicity of Dirofilaria repens," PLoS Neglected Tropical Diseases, vol. 10, no. 5, article e0004547, 2016.

[11] M. Miterpáková, D. Antolová, F. Ondriska, and V. Gál, "Human Dirofilaria repens infections diagnosed in Slovakia in the last 10 years (2007-2017)," Wiener Klinische Wochenschrift, vol. 127, no. 17-18, pp. 634-641, 2017.

[12] S. Laaksonen, M. Solismaa, R. Kortet, J. Kuusela, and A. Oksanen, "Vectors and transmission dynamics for Setaria tundra (Filarioidea; Onchocercidae), a parasite of reindeer in Finland," Parasites \& Vectors, vol. 2, p. 3, 2009.

[13] A. M. Ionică, C. Zittra, V. Wimmer et al., "Mosquitoes in the Danube Delta: searching for vectors of filarioid helminths and avian malaria," Parasites \& Vectors, vol. 10, no. 1, p. 324, 2017.

[14] H. L. Enemark, A. Oksanen, M. Chriél, J. le Fèvre Harslund, I. D. Woolsey, and M. N. Al-Sabi, "Detection and molecular characterization of the mosquito-borne filarial nematode Setaria tundra in Danish roe deer (Capreolus capreolus)," International Journal for Parasitology: Parasites and Wildlife, vol. 6, no. 1, pp. 16-21, 2017.

[15] S. Laaksonen, M. Solismaa, T. Orro et al., "Setaria tundra microfilariae in reindeer and other cervids in Finland," Parasitology Research, vol. 104, no. 2, pp. 257-265, 2009.

[16] S. Laaksonen, J. Kuusela, S. Nikander, M. Nylund, and A. Oksanen, "Outbreak of parasitic peritonitis in reindeer in Finland," Veterinary Record, vol. 160, no. 24, pp. 835-841, 2007.

[17] K. Lebl, C. Zittra, K. Silbermayr et al., "Mosquitoes (Diptera: Culicidae) and their relevance as disease vectors in the city of Vienna, Austria," Parasitology Research, vol. 114, no. 2, pp. 707-713, 2015.

[18] C. Zittra, S. Vitecek, A. G. Obwaller et al., "Landscape structure affects distribution of potential disease vectors (Diptera: Culicidae)," Parasites \& Vectors, vol. 10, no. 1, p. 205, 2017.

[19] N. Becker, D. Petric, M. Zgomba et al., Mosquitoes and Their Control, Springer, Heidelberg, Germany, 2nd edition, 2010.

[20] A. Hodžić, A. Alić, H. P. Fuehrer, J. Harl, W. Wille-Piazzai, and G. G. Duscher, "A molecular survey of vector-borne pathogens in red foxes (Vulpes vulpes) from Bosnia and Herzegovina," Parasites \& Vectors, vol. 8, p. 88, 2015.

[21] C. Silaghi, R. Beck, G. Capelli, F. Montarsi, and A. Mathis, "Development of Dirofilaria immitis and Dirofilaria repens in Aedes japonicus and Aedes geniculatus," Parasites \& Vectors, vol. 10, no. 1, p. 94, 2017.

[22] M. Miterpáková, A. Iglódyová, V. Čabanová, E. Stloukal, and D. Miklisová, "Canine dirofilariosis endemic in Central Europe-10 years of epidemiological study in Slovakia," Parasitology Research, vol. 115, no. 6, pp. 2389-2395, 2016. 
[23] A. Trájer, A. Rengei, K. Farkas-Iványi, and A. Bede-Fazekas, "Impacts of urbanisation level and distance from potential natural mosquito breeding habitats on the abundance of canine dirofilariosis," Acta Veterinaria Hungarica, vol. 64, no. 3, pp. 340-359, 2016.

[24] G. Duscher, A. Feiler, W. Wille-Piazzai et al., "Detection of Dirofilaria in Austrian dogs," Berliner und Münchener tierärztliche Wochenschrift, vol. 122, no. 5-6, pp. 199-203, 2009, in German.

[25] A. Bacsadi, A. Papp, L. Szeredi et al., "Retrospective study on the distribution of Dirofilaria immitis in dogs in Hungary," Veterinary Parasitology, vol. 220, pp. 83-86, 2016.

[26] E. Bocková, A. Iglódyová, and A. Kočišová, "Potential mosquito (Diptera:Culicidae) vector of Dirofilaria repens and Dirofilaria immitis in urban areas of Eastern Slovakia," Parasitology Research, vol. 114, no. 12, pp. 4487-4492, 2015.

[27] C. Zittra, Z. Kocziha, S. Pinnyei et al., "Screening blood-fed mosquitoes for the diagnosis of filarioid helminths and avian malaria," Parasites \& Vectors, vol. 8, p. 16, 2015.

[28] K. Büttner, "Untersuchungen zur Parasitierung des Rehwildes bei steigendem Jagddruck," Zeitschrift für Jagdwissenschaft, vol. 24, no. 3, pp. 139-155, 1978.

[29] C. Czajka, N. Becker, S. Poppert, H. Jöst, J. Schmidt-Chanasit, and A. Krüger, "Molecular detection of Setaria tundra (Nematoda: Filarioidea) and an unidentified filarial species in mosquitoes in Germany," Parasites \& Vectors, vol. 5, p. 14, 2012.

[30] G. Kemenesi, K. Kurucz, A. Kepner et al., "Circulation of Dirofilaria repens, Setaria tundra, and Onchocercidae species in Hungary during the period 2011-2013," Veterinary Parasitology, vol. 214, no. 1-2, pp. 108-113, 2015.

[31] A. Werblow, E. Flechl, S. Klimpel et al., "Direct PCR of indigenous and invasive mosquito species: a time- and costeffective technique of mosquito barcoding," Medical and Veterinary Entomology, vol. 30, no. 1, pp. 8-13, 2016.

[32] A. Masny, R. Sałamatin, W. Rozej-Bielicka, and E. Golab, "Is molecular xenomonitoring of mosquitoes for Dirofilaria repens suitable for dirofilariosis surveillance in endemic regions?," Parasitology Research, vol. 115, no. 2, pp. 511-525, 2016. 


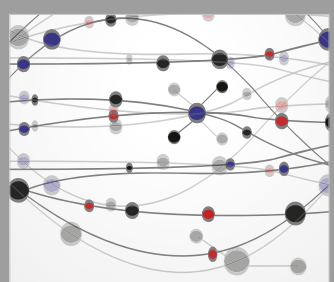

The Scientific World Journal
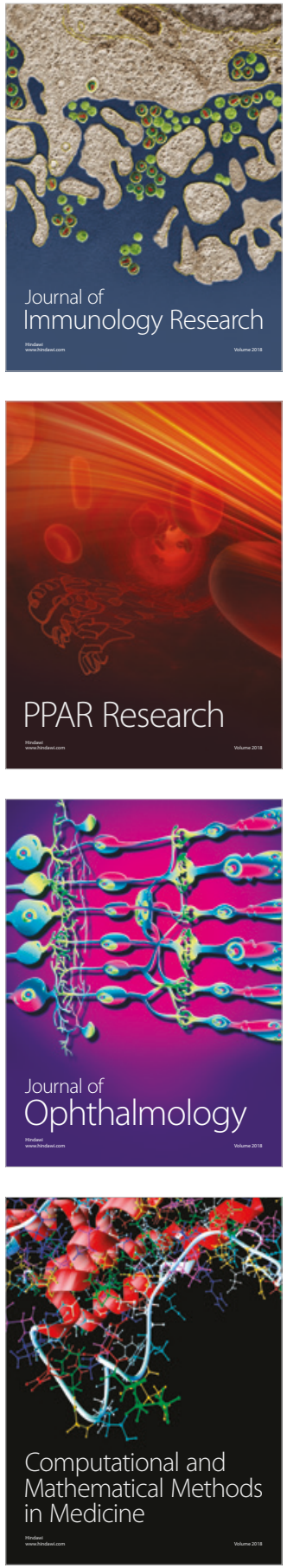

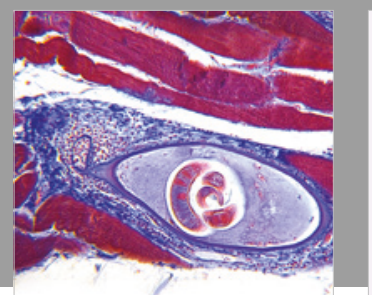

Gastroenterology Research and Practice

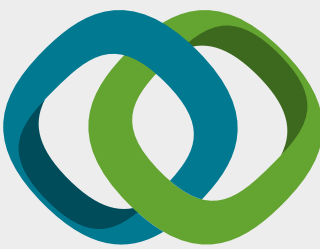

\section{Hindawi}

Submit your manuscripts at

www.hindawi.com
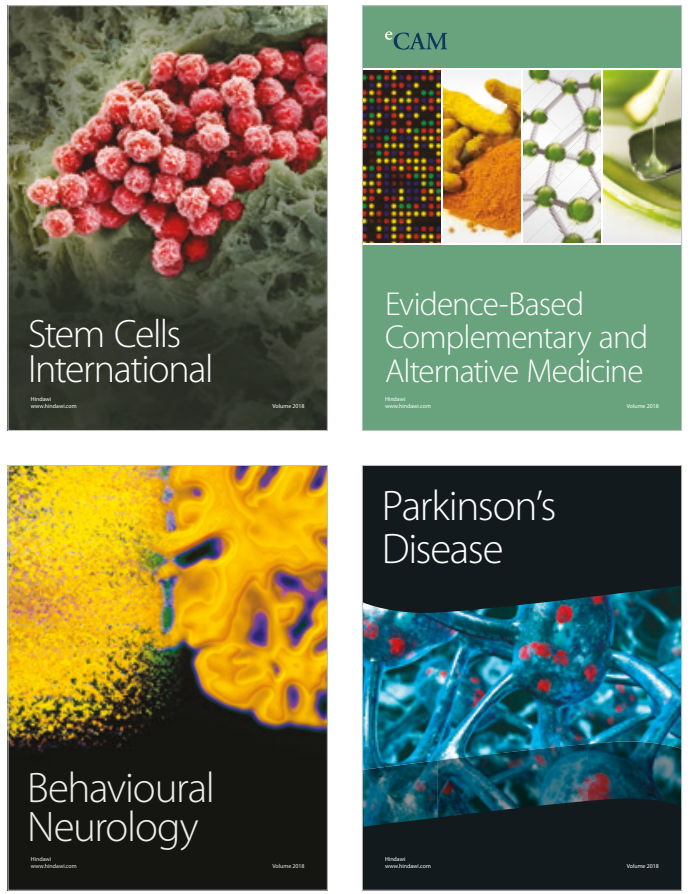

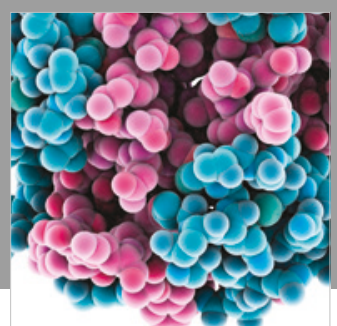

ournal of

Diabetes Research

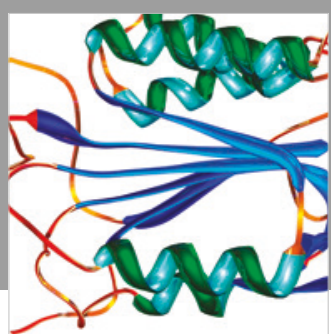

Disease Markers
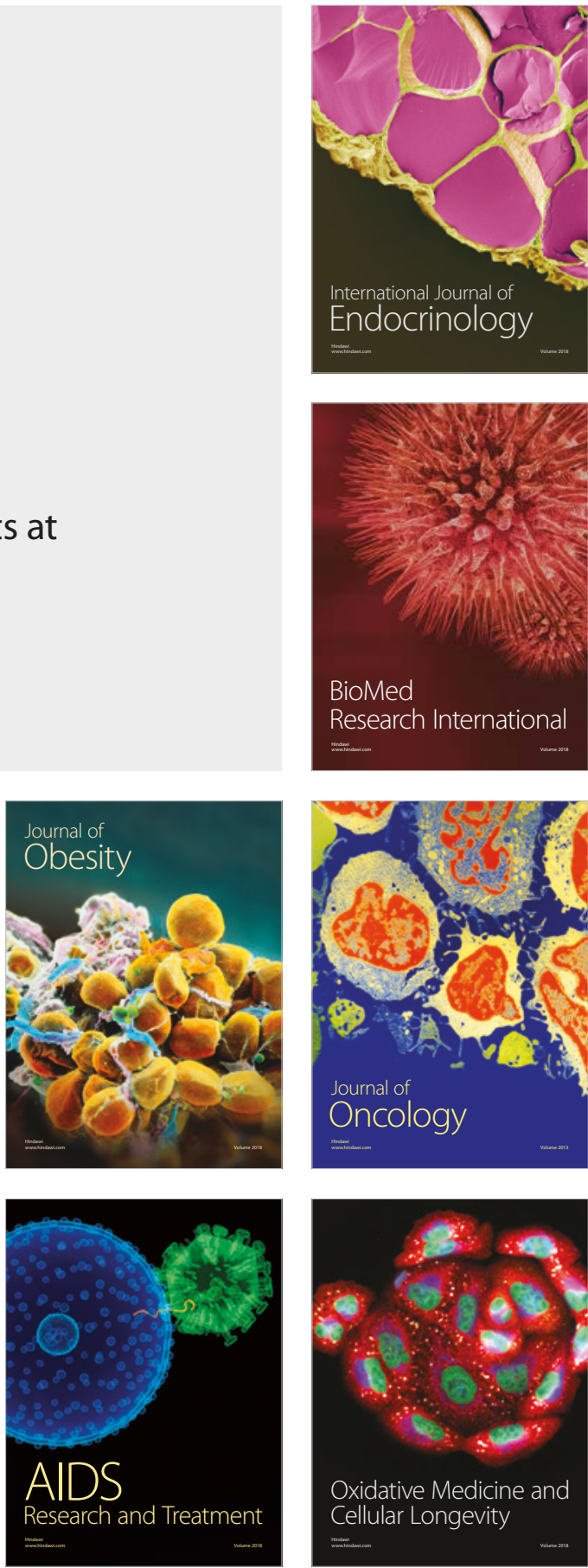